shape in Ptilodus given by Simpson ${ }^{1}$ does not seem to bo very probable.

In the occipital plate (Fig. $1 b$ ), there is an extensive tabular which occupies the entire region between the occipital and lambdoidal crest. In the lower part of the tabular there is an unusually large post-temporal fossa. The triangular paroccipital process (in the reptilian sense) is also characteristic of the occipital region of Kamptobaatar.

The structures I have doscribed show that the skull of Cretaceous multituberculates is characterized by a juxtaposition of primitivo (therapsid) and advanced (mammalian) characters. Tho general pattern of the multituberculato braincaso, in contradistinction to the opinion of Simpson ${ }^{1}$, is essentially the same as in the monotremes (Fig. 2). On the other hand, the studied ear region and the triradiate structure of the choanal region strongly resemble those in triconodonts ${ }^{9}$ and docodonts (Morganucodon $)^{10}$. This new information on the skull structure in multituberculates confirms tho opinion of Kermack ${ }^{11}$, that the Monotromata, Multitubereulata, Triconodonta and Docodonta form ono subclass Prototheria, equivalent to the Thoria. The Multituberculata are, however, more allicd to the Monotremata than they are to the Docodonta and Triconodonta. It seems that there is no reason to place the Multituberculata in the subclass of their own, Allotheria ${ }^{12}$, and the theory of the polyphyletic origin of mammals ${ }^{13}$ eannot be meintained.

I thank Dr K. A. Kermack, Zoology Department, University College, London, for discussion and for placing at my disposal the undescribed specimen of Morganucodon from China for an examination, and Dr L. P. Tatarinov, Palaeontological Institute, USSR Academy of Scicnces, Moseow, for criticism and commonts.

Palacozoological Institute,

Polish Academy of Sciencos,

Warsaw,

Received April 1, 1970.

1 Simpson, G. G., Bull. Amer. Mus. Nat. Hist., 73, 727 (1937).

¿ Clemens, A. W., Univ. Calif. Publ. Geol. Sci., 48, 1 (1963).

${ }^{3}$ Sloan, R. E., and Van Valen, L., Science, 148, 220 (1965).

4 Tillegraven, J. A., Paleont. Contrib. Univ. Kans., 50, 1 (1969).

s Kielan-Jaworowska, Z., and Dovchin, N., Y'al. Polonica, 19, 7 (1068/69).

- Kielau-Jaworowska, Z., Pal. Polonica, 21, 35 (1970).

"Kielan-Jaworowska, Z., Nature, 222, 1091 (1969).

s Tatarinov, I. P., I'aleont. Inst. USSR Acad. Sci. (Diss. abstr.) (1969).

- Kermack, K. A., Phil. Trans. Roy. Soc., 246, 88 (1963).

${ }^{10}$ Rigney, F. H. W., Nalure, 197,1122 (1963).

"Kormack, K. A., J. Linn. Soc. (Zool.), 47, 241 (1967).

${ }^{13}$ Simpson, G. (रे., Bull. Amer. Mus. Nat. Hist., 851 (1945).

${ }^{13}$ Simpson, G. G., Evolution, 13, 404 (1959).

\section{Corophium curvispinum (Amphipoda) recorded again in the British Isles}

Corophium curvispinum Sars. (Amphipoda: Ccrophidae) is a tubicolous crustacean which is spreading through the freshwaters of Europe, but has only been recorded twice before in the British Isles - once in the River Avon at Tewkesbury in $1935^{1}$ (thirteen specimens), and at Stourport on Severn in 1962 (personal communication from R. W. Inglc) (sixteen specimens). In 1960, Corophium could not be found again at Tewkesbury ${ }^{2}$.

Corophium has now bcen found in the Grand Union Canal in Leicestershire between Newton Bottom Lock (SP.631966) half a mile west of Newton Harcourt church, and at bridge 76 (SP.654941) half a wile north-east of Fleckncy church. This represents a canal distance of approximately three miles. The collections were made between October 28, 1969, and February 11, 1970.

Tho collections have so far been concentrated on the Fontinalis, algae, silt and sponge debris on the brickwork of locks and bridges. The abundance and distribution of Corophium seem to be variable. Twenty or thirty specimens were collected quite casily at Nowton Middle Lock (Spinney Lock), and at bridge 76 a hundred specimens could be picked out in a few minutes. Other collections yielded one or two specimens or none at all.

Now that Corophium is known to occur in tho canal, a fuller survey is being made. There is also the possibility that a second species, Corophium spongicolum, may be found because sponges, on which it lives, are common in the locks and under bridges. Originally, Corophium curvispinum in freshwater was referred to as a variety 'devium'3. The latest opinion ${ }^{4}$ is that two spocies, $C$. curvispinum and spongicolum, occur together in fresh. water. It is difficult to understand how this animal has been overlooked until now, in viow of the frequent collections that have been made over the years in the canal.

The discovery of Corophium in the canal was due to the recognition by a student, Miss Marion J. Gray, of a single specimen of an unusual crustacean, in a collection mado by a ficld class from tho School of Biological Sciences, University of Leicester.

I thank Dr R. W. Ingle of the British Museum (Natural History), who eonfirmed the identification and provided me with the latest information on the systematies of Corophium.

School of Biological Sciences,

H. P. MooN

University of Leicester.

Received March 11, 1970.

'Crawford, G. I., Nature, 136, 685 (1935).

${ }^{2}$ Scient. Publs. Freshwater Biol. Ass., No. 19, 14 (1960).

${ }^{3}$ Crawford, G. I., J. Mar. Biol. Ass, UK, 21, 602 (1937).

- Straskraba, M., Vêst Csl. Spol. Zool., 26, 140 (1962).

\section{Ethylene and the Respiration Climacteric}

MANy theories have been proposed to explain tho nature of the elimacterie rise in respiration seen in most ripening fruits. They include changes in tissue organization which lead to inereased metabolism ${ }^{1}$, or effects of mitochondria which cause a loss of respiratory control". The role of ethylene in the induction of ripening has now been confirncd but, in spite of much attention, the physiological nature and significance of the climactoric have remained elusive ${ }^{3}$. Althongh fruit, tissues undergo many changes during ripening ${ }^{4}$, much biochemical organization is re. taincd; mitochondria do not lose their respiratory control ${ }^{2}$ and protein synthesis continues up to the climacteric maximum ${ }^{5-7}$. Ripening has thereforo been interpreted as a process requiring considerable cellular work, so that the climacteric is merely the respiratory summation of cellular energy requirements ${ }^{3}$. In many fruits, however, the energy requirements for the largely catabolic events of ripening must be very small. In the banana, for example, which shows a classical respiration climacteric, starch makes up as much as 20 per cent of the fresh weight before ripening ${ }^{8}$. During ripening, the starch is almost completely hydrolysed by phosphorylase to sugars (an exergonic reaction). Moreover, it has been shown that the respiratory climacteric ean oceur in the absence of protein synthesis ${ }^{6}$.

The respiratory climacteric scerns to be almost invariably assuciated with endogenous production of high concentrations of ethylene ${ }^{3}$, the ethylene evolved after ripening begins being far grcater than the amount that was required to start ripening in tho same fruit. Some fruits ("non-climacteric" fruits) show no clear-cut respiratory climacteric and cvolve very little ethylene during riponing. If such fruits aro troated with ethylene (Fig. 1a), however, they show a marked respiratory rise, quite like a climacteric in time and magnitude. There secms there. 